\title{
The Impact Of Productive Zakat On The Economic Empowerment Program Based On Social Return On Investments (SROI): Case Study Of PT Karya Masyarakat Mandiri
}

\author{
Shofia Hidayat ${ }^{1}$, Hendro Wibowo ${ }^{2}$, Muhammad Doddy ${ }^{3}$
}

${ }^{1}$ SEBI: hidayat.shofia@gmail.com

${ }^{2}$ SEBI Lecturer \& Doctoral Candidate AeU Malaysia, Email : hendro.wibowo83@gmail.com ${ }^{3}$ SEBI Lecturer \& Doctoral Candidate AeU Malaysia, Email : doddy.abe@ gmail.com

\begin{abstract}
Various programs are presented in zakat distribution practice. Productive zakat is one type of zakat that can provide sustainable benefits for the zakat mustahiq. PT KMM is a Social Enterprise formed by Dompet Dhuafa to focus on providing empowerment programs to the community as an effort to alleviate poverty. As an institution funded by zakat funds, PT KMM requires evidence on the impact and the extent of the impact of empowerment program that has been implemented for the sake of transparency of the distributed zakat funds. This study aims to calculate the impact produced by PT KMM using Social Return on Investment (SROI). The result of this study indicates that the SROI ratio was 4.89: 1. It means every Rp. 1 invested has generated benefit approximately Rp. 4.98 on economic, social and environment. This means that the empowerment program in the form of the Green Hortim M3 program through the Sumber Jaya Tani Community has the capability to yield benefits of 4.89 times greater than the input value invested.
\end{abstract}

Keywords: Zakat, Productive Zakat, Empowerment, Social Impact, Economic Impact, Environmental Impact, Social Return on Investment.

\section{INTRODUCTION}

The potential of zakat which is seen from the amount of zakat collection every year always increases in number. The total collection of zakat in 2017 is 6.2 trillion Rupiah (2017 Baznas).

The collection of zakat funds is inseparable from the distribution of zakat funds themselves as zakat will not provide benefits and meaning if it is not distributed. Besides being reviewed in terms of collection and distribution, one of the indicators which shows that zakat management organizations are running effectively is by reviewing the absorption rate (Baznas 2018).

The development in the world of zakat is increasingly rapid, whose existence is increasingly seen, as evidenced by the emergence of many Amil Zakat Institutions which contribute to maximizing the potential of charity which is quite large. The growth of zakat is seen in one of the Amil Zakat Institutions such as Dompet Dhuafa (DD) as a pioneer zakat institution which was formed for the first time in Indonesia and has become a national level Amil Zakat Institution. It started from four collective teams of journalists who have concern 
80 | Shofia Hidayat, Hendro Wibowo, Muhammad Doddy: The Impact of Productive Zakat on The Economic Empowerment Program Based on Social Return on Investments (SR0I)

for the poor and then got together to form an independent institution with the name Dompet Dhuafa Republika. It continued to the opening of the rubric of the page with the title "Dompet Dhuafa" on July 2, 1993. The date is then made into the anniversary of the organization that we have known for long.

The trust of the community to the Amil Zakat Institution increases as seen in the growth of zakat funds collected by Dompet Duafa. The potential for large zakat must certainly be balanced with effective distribution. One indicator that shows that zakat management organizations are running effectively is by reviewing the absorptive level based on total collection funds that have been channeled effectively (Puskas 2017).

Program innovations continue to be carried out to expand and create greater impact. One solution to creating a large impact from zakat funds is productive zakat through a community empowerment program. Productive distribution patterns (empowerment), namely by providing grants sourced from zakat and mandated to build a business with the aim of improving the condition of mustahik. Zakat itself has a sustainable goal to motivate mustahik to turn into muzaki. Because among the goals of zakat is to abolish kafakiran, poverty, and equipment. (Hasan 2003, 37).

Pratama (2015) states that zakat will be able to provide a wider multiplier effect, and affect all aspects of life, if the distribution of zakat is more directed to those activities that are productive. Jamal (2004) argues that zakat utilization also needs to be done towards long-term investment. This can be in the form of sharing to maintain incentives to work or earn their own income in the poor. Second, a portion of the collected charity, at least $50 \%$ is used to finance productive activities for the poor, for example the use of zakat to finance various activities and training in productive skills, providing working capital, or initial capital assistance. If the distribution of zakat is managed in the ways mentioned above, it will greatly help government programs in alleviating poverty, equalizing income, and narrowing the gap between the rich and the poor.

To get the zakat benefit opportunities to touch the community, Dompet Dhuafa develops empowerment programs with productive zakat systems. Dompet Dhuafa forms a network unit whose job is more on community empowerment activities called Community Enterprise or CE. One of them is PT Karya Masyarakat Mandiri (KMM). One of the empowerment programs carried out by PT KMM is the Green Horti Program which is located in Cipanas. The Green Horti program is an economic empowerment program that is formed in the community association.

From year to year, there is a continuous increase in both collection and distribution. Aside from the absorption of zakat on its distribution program, which also needs to be considered in assessing the effectiveness of zakat funds, how much impact can be made by the zakat distribution program. Does zakat that has been channeled have a positive impact on the community and how much impact has resulted from the zakat itself?

One of the tools used to calculate the impact of social investment funds that can account for the impact accountably is SROI. In a program that runs for the welfare of the people who use the community funds themselves, there needs 
Jurnal Ekonomi dan Perbankan Syariah

Vol. 7. No.1, April 2019: 79-94 ISSN (cet): 2355-1755 | ISSN (online): 2579-

6437

| 81

to be an accountable and transparent system. Not only in terms of fund management, but also how much value they have to measure from various programs that have been funded, the need for tools to evaluate the impact of the program includes Social Return on Investments (SROI). Maler, Schober, Simsa, and Millner (2015) found that nearly 40 methods that had and in the realization of an accountable and transparent system, one of which was SROI.

From the presentation that has been delivered, according to the author, it is necessary to calculate the number of impacts that exist on the zakat program, looking at the influence and potential. Thus, the extent to which this program has an impact on the community and the evaluation and what policies will be taken from the program so as to further increase its usefulness to the wider community as well as the function of zakat itself. With that the author is interested in reviewing and analyzing the calculation of the impact of the empowerment program at the Dompet Dhuafa Amil Zakat Institution under the management of PT Karya Masyarakat Mandiri.

\section{LITERATURE REVIEW}

\section{PRODUCTIVE ZAKAT AND EMPOWERMENT PROGRAM}

\section{The Obligation of Zakat}

Judging from the language, the word zakat is the basic word (masdar) of zaka which means blessing, clean, growing, and good (Qardawi 2011, 34). In the Sunnah fiqh book written by Sayyid Sabiq, zakat is the name of something God has issued by someone to the poor. It is called zakat because it contains hope to get blessings, cleanse, and cultivate the soul with various goodness (Sayyid 2006, 497). The order to fulfill zakat is stated in the Qur'an:

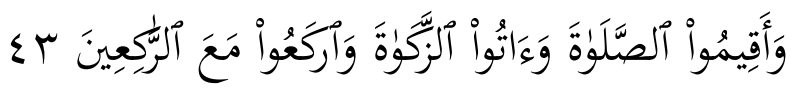

"And establish prayer and give zakah and bow with those who bow [in worship and obedience." (Q.S Al- Baqarah [2]: 43)

In a hadith, it is also explained about the obligation of zakat

"Islam is built on five (pillars): bearing witness that there is no god except Allaah and that Muhammad is the Messenger of Allah, establishing prayer, paying zakaah, Hajj and fasting Ramadan." (Hadist Mutafaq Alaih)

In law as a source of law in a country mentioning the law of zakat itself. In Law No. 23 of 2011 affirms that fulfilling zakat is an obligation for Muslims who are able to conform to the Islamic shari'a. 
82 | Shofia Hidayat, Hendro Wibowo, Muhammad Doddy: The Impact of Productive Zakat on The Economic Empowerment Program Based on Social Return on Investments (SR0I)

\section{Productive Zakat and Empowerment}

Productive Zakat is zakat which is managed in a productive manner, which is done by giving business capital to the needy and poor as recipients of zakat and then developing it to fulfill their daily needs. (Rusli, Abubakar Hamzah 2013).

Etymologically, empowerment comes from the basic word "power" which means strength or ability. Empowerment is a program of engagement and enhancement of community participation originating from community-based because it suits their needs and aspirations, as well as advocacy programs because the role of outsiders is limited to assisting and providing alternative problem solving to the community (P.H. and Nikijuluw 2001).

Empowerment needs some attention, especially when starting the program. Sumodiningrat gives the opinion that community empowerment must be carried out through 3 (three) channels, namely: (1) Creating a climate that enables the potential of developing communities (Enabling); (2) Strengthening the potential and power of the community (Empowering); (3) Providing protection (Protecting). Community empowerment is an effort to improve quality and is one of the solutions to exclude people from the shackles of poverty (Kurniawati, Supriyono, and Hanafi 2013).

Impact is a measure of the level of influence of social, economic, environmental, or other public interests that begins with the achievement of the performance of each indicator in an activity (Dicktus, 2013). According to the Ministry of Social Affairs, it is explained that social impact is the effect or effect of an event, a situation, a policy that results in changes that are both positive and negative for the social environment and social conditions.

According to Irawan (2013) describing the economic impact is an economic impact arising from operational activities that affect the local, national, and global economic system which consists of three types of economic impacts, namely direct, indirect, impact / continued economic impacts.

Meanwhile, Soemarwoto (2005) describes the environmental impact as a change that occurs as a result of an activity where the activity can be natural, both chemical, physical and biological.

\section{SOCIAL RETURN ON INVESTMENTS (SROI)}

The definition of social return on investments (SROI) is "A framework for measuring and accounting for this much broader concept of value; it is as close to quality and innovative degradation as improving social wellbing by incroporation, environmental and economic costs and benefits. "(Nicholas, lawlor, Neitzert, and Goodspeed, 2009)

SROI is a method that can be used to measure the impact seen from three aspects, namely, social, environmental, and economic (Purwohedi, 2016). The value generated from this method contains all three impacts. These impacts can be enjoyed by stakeholders because of an activity carried out by an organization that has provided a number of resources for these activities. The formula of SROI as follows. 
Jurnal Ekonomi dan Perbankan Syariah

Vol. 7. No.1, April 2019: 79-94 ISSN (cet): 2355-1755 | ISSN (online): 2579-

6437

| 83

SROI Ratio $=($ Net Present Value of Benefit $) /($ Value of Inputs $)$

The meaning of net present value is cash flow that is expected in the future to be discounted at this time. Then the meaning of value of inputs is total funds invested.

\section{METHODOLOGY}

\section{RESEARCH AND SAMPLING FRAMEWORK}

This research is descriptive quantitative research. The types of data used are primary and secondary. The collection technique uses three ways, namely interviews, questionnaires, and observations. The population in this study was the Sumber Jaya Tani association which took place in the village of Sindang Jaya Cianjur with a population of 27 people.

The sampling technique used was simple random sampling. The number of samples taken using the Slovin formula.

\section{RESEARCH INSTRUMENTS}

This research has several research instruments. The research instruments are as follows:

Table 1: Research Instruments

\begin{tabular}{|c|c|c|c|}
\hline No. & Variabel & Indicators & Impacts \\
\hline \multirow[t]{7}{*}{1.} & \multirow[t]{7}{*}{ Economy } & \multirow{3}{*}{$\begin{array}{l}\text { direct effect } \\
\text { (Stynes,2013) }\end{array}$} & Increased revenue \\
\hline & & & Sales \\
\hline & & & Tax income \\
\hline & & \multirow{2}{*}{$\begin{array}{l}\text { indirect effect } \\
\text { (Stynes,2013) }\end{array}$} & Price level changes \\
\hline & & & quality change \\
\hline & & induced effects & Increased purchasing power \\
\hline & & (Stynes,2013) & \\
\hline \multirow[t]{4}{*}{2.} & \multirow[t]{4}{*}{ Social } & Impact of & Mutual cooperation \\
\hline & & individual and & \\
\hline & & collective values & \\
\hline & & (Douglas,2013) & \\
\hline
\end{tabular}


84 | Shofia Hidayat, Hendro Wibowo, Muhammad Doddy: The Impact of Productive Zakat on The Economic Empowerment Program Based on Social Return on Investments (SR0I)

Social relations Kinship
behavior

(Douglas,2013)

3. Environment Physical and Soil fertility

chemical impacts Water quality

(Suratmo,1990) Air quality

Biological impact Number of animals

(Suratmo,1990)

\section{RESEARCH PROCESS}

Research on empowerment programs through productive zakat through several stages. The stages of this research are as follows:

\section{Figure 1: Research Process}

\section{Impacts:}

- Economy

- Social

- Environment
SROI

Evaluation

Methods 
Jurnal Ekonomi dan Perbankan Syariah

Vol. 7. No.1, April 2019: 79-94 ISSN (cet): 2355-1755 | ISSN (online): 2579-

6437

| 85

\section{RESULTS AND DISCUSSION}

\section{ESTABLISHING SCOPE AND STAKEHOLDERS}

The Green Horti M3 program is one of the community economic empowerment programs at PT KMM. With the concept of ideas for the development of vegetable agriculture with market orientation and adoption of appropriate healthy agricultural technology (TPSTG). The program is conceptualized to assisted farmers where farmers are assisted to build up the maximum efficient and maintenance of agricultural productivity in crop yields, as well as processing of crops until the results can be distributed to the market.

The activities carried out in the Green Horti M3 program are empowerment of agricultural communities that use agricultural technology on target and are effective with sources of fertility funds originating from zakat managed by the Dompet Dhuafa and PT KMM as facilitators for channeling and mentoring programs. In this program farmers are assisted in maximizing their productivity by being provided with various agricultural skills training and also being accompanied in terms of packing so that the harvest can be marketed and accepted by potential markets. In addition to mentoring the Green Horti program, it also provides capital assistance and facilities to support the empowerment program. The source of funding to support this empowerment program is zakat funds managed by the Dompet Dhuafa.

The Green Horti empowerment program has goals that have been designed in advance in the initial concept. The aim of this program is to improve the economic well-being of the assisted community, the establishment of a horticulture development center in Cianjur, and improve the quality of the human resources of the target groups to support the Green Horti program.

\section{Inputs of Program}

The source of funding to support this empowerment program is the zakat fund managed by Dompet Dhuafa. The following are details of the financial assistance provided by Dompet Dhuafa through KMM as input.

\begin{tabular}{lr}
\hline \multicolumn{1}{c}{ Inputs } & Value of Input \\
\hline $\begin{array}{l}\text { Grant assistance for horticultural open land } \\
\text { farming 6 hectares, 30 }\end{array}$ & Rp. 270.000.000 \\
\hline Development assistance of Green House 1 & Rp. 310.000 .000 \\
\hline Assistance for Green House farming input & Rp.55.000.000 \\
\hline $\begin{array}{l}\text { Strengthening of organic farming technical } \\
\text { skills (fertilization, pesticide application, } \\
\text { etc.) }\end{array}$ & Rp. 18.198 .600 \\
\hline Procurement of 1 unit of vehicle & Rp. 69.000 .000 \\
\hline The vegetable packing house & Rp. 18.002 .500 \\
\hline
\end{tabular}


86 | Shofia Hidayat, Hendro Wibowo, Muhammad Doddy: The Impact of Productive Zakat on The Economic Empowerment Program Based on Social Return on Investments (SR0I)

\begin{tabular}{lr}
\hline $\begin{array}{l}\text { Development of superior vegetable markets } \\
\text { (packaging, marketing, etc.) }\end{array}$ & Rp. 7.180 .400 \\
\hline Farmer social gathering & Rp. 30.000 .000 \\
\hline $\begin{array}{l}\text { Management training (planning, marketing, } \\
\text { etc.) }\end{array}$ & Rp. 8.787 .500 \\
\hline farmer organization management training & Rp. 5.213 .300 \\
\hline Legalization of local legal entity & Rp. 7.500 .000 \\
\hline Total & Rp. 798.882 .300 \\
\hline
\end{tabular}

\section{Determining Stakeholders}

The first step is to determine stakeholders. The following are various stakeholder tables that are set to be included and not included:

Table 2: List of Stakeholders

\begin{tabular}{lll}
\hline \multicolumn{1}{c}{$\begin{array}{l}\text { Stakeholders Entered } \\
\text { Stakeholders }\end{array}$} & $\begin{array}{c}\text { Entered in SROI } \\
\text { Analysis }\end{array}$ & \multicolumn{1}{c}{ Reason to be Entered } \\
\hline Sumber Jaya Tani & Yes & Because the organizers and \\
Association & & $\begin{array}{l}\text { members of the association as } \\
\text { stakeholders feel the impact } \\
\end{array}$ \\
& directly from the Green Horti \\
& program
\end{tabular}

\begin{tabular}{lll}
\hline \multicolumn{2}{l}{ Stakeholders Not Entered } \\
\hline Stakeholders & Not Entered in & Reason to be Not Entered \\
& SROI Analysis
\end{tabular}

\begin{tabular}{lll}
$\begin{array}{l}\text { Program } \\
\text { companion } \\
\text { (PT KMM) }\end{array}$ & No & $\begin{array}{l}\text { Because the program companion } \\
\text { takes a very significant role in } \\
\text { the sustainability of the program } \\
\text { but does not feel the direct } \\
\text { impact of the program's own } \\
\text { objectives. }\end{array}$ \\
\hline Local government & No & $\begin{array}{l}\text { Because it does not have a } \\
\text { significant role and does not feel } \\
\text { the impact directly. }\end{array}$ \\
\hline Dompet Dhuafa & No & $\begin{array}{l}\text { Have a role as a provider of } \\
\text { funds but do not feel the impact } \\
\text { directly. }\end{array}$ \\
\hline
\end{tabular}


Jurnal Ekonomi dan Perbankan Syariah

Vol. 7. No.1, April 2019: 79-94 ISSN (cet): 2355-1755 | ISSN (online): 2579-

6437

\section{| 87}

\section{Mapping and Proving Impacts}

After determining the scope and analyzing the stakeholders, the next step is to map the impact of all perceived benefits. In mapping the impact of the analysis carried out by conducting discussions with stakeholders so that the results of the analysis can be relevant to the facts in the field. In the impact mapping, two key informants were involved, namely program facilitators and the Sumber Jaya Tani association. Data taken from the results of interviews and questionnaires provided. There is a mapping of impacts:

\section{Figure 2: Mapping of Impacts}

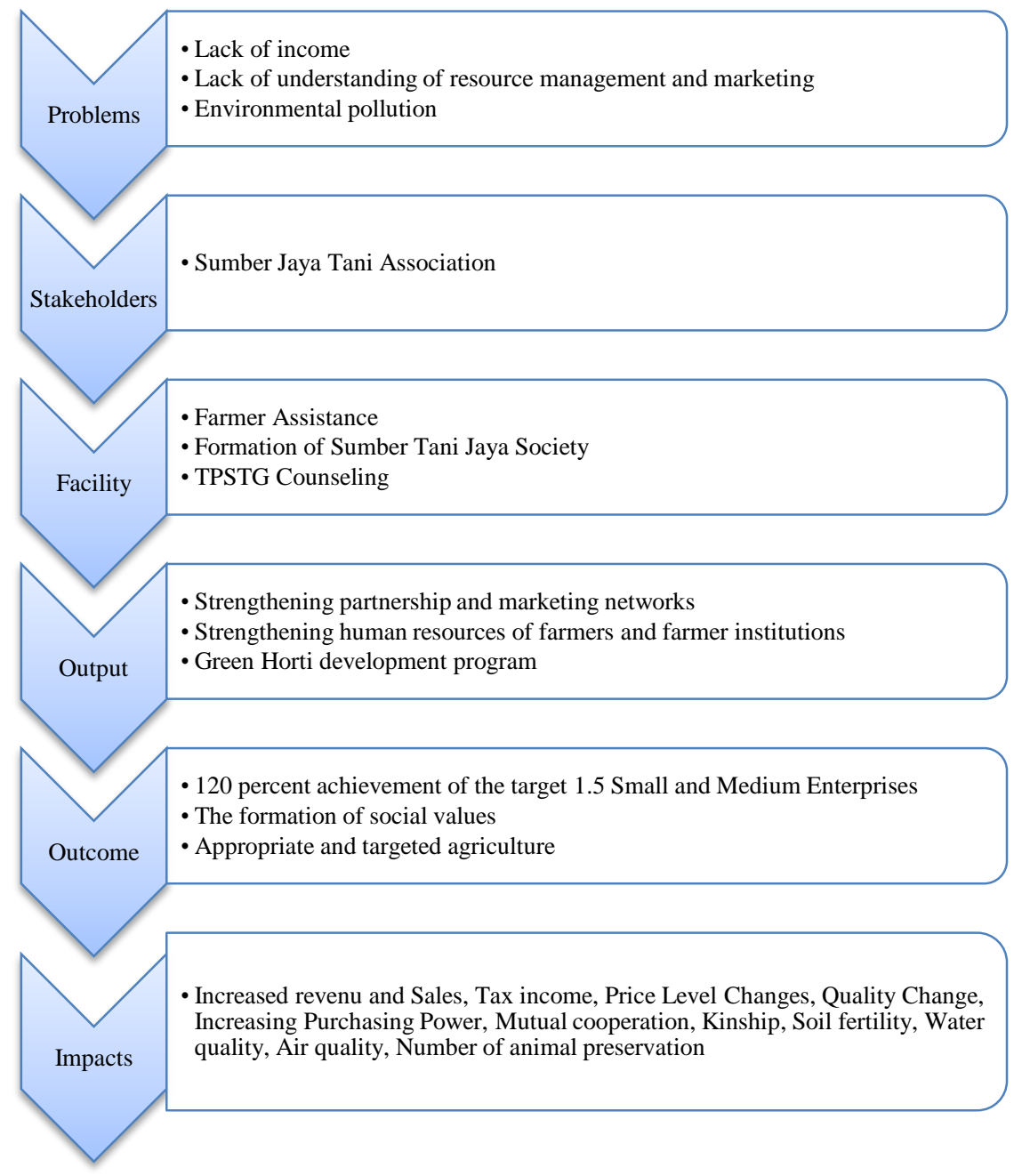


88 | Shofia Hidayat, Hendro Wibowo, Muhammad Doddy: The Impact of Productive Zakat on The Economic Empowerment Program Based on Social Return on Investments (SR0I)

\section{Prove the Impact and Give Value}

The next stage of the SROI analysis is finding evidence that an impact actually occurs and is felt by the beneficiaries. An indicator is a condition or fact in the field that can be used as a basis for SROI users that the change really happens. The indicator used in this analysis is the tabulation of the questionnaire.

\section{Table 3: Outcomes of Program}

\begin{tabular}{|c|c|c|}
\hline No. & Outcome & Indicators \\
\hline 1 & Increased revenue & $\begin{array}{l}\text { From the results of the } 96 \% \\
\text { questionnaire and the program reports } \\
\text { listed in appendix } 9 \text {, there is evidence } \\
\text { that there is an increase in income after } \\
\text { the program. }\end{array}$ \\
\hline 2 & Sales & $\begin{array}{l}\text { From the results of the } 96 \% \\
\text { questionnaire and the program reports } \\
\text { listed in appendix } 9 \text {, it was proven and } \\
\text { there was an increase in sales after the } \\
\text { program. }\end{array}$ \\
\hline 3 & Tax income & $\begin{array}{l}\text { From the results of the questionnaire } \\
60 \% \text { or } 15 \text { respondents stated that they } \\
\text { could pay taxes after the program. }\end{array}$ \\
\hline 4 & Price Level Changes & $\begin{array}{l}\text { From the results of the questionnaire, } \\
100 \% \text { or } 25 \text { people stated that there was } \\
\text { a change in the price level after the } \\
\text { program. }\end{array}$ \\
\hline 5 & Quality Change & $\begin{array}{l}\text { From the results of the questionnaire, } \\
96 \% \text { or } 24 \text { respondents stated that there } \\
\text { was a change in the quality of the crop } \\
\text { and would continue to maintain the } \\
\text { quality of the crop after the program. }\end{array}$ \\
\hline 6 & $\begin{array}{l}\text { Increasing Purchasing } \\
\text { Power }\end{array}$ & $\begin{array}{l}\text { From the results of the questionnaire, } \\
88 \% \text { or } 22 \text { respondents stated that there }\end{array}$ \\
\hline
\end{tabular}


was additional purchasing power after the program.

7 Mutual cooperation From the results of the questionnaire, $100 \%$ or 25 respondents stated that there was mutual cooperation between members after the program.

\begin{tabular}{|c|c|c|}
\hline 8. & Kinship & $\begin{array}{l}\text { From the results of the questionnaire, } \\
100 \% \text { or } 25 \text { respondents stated that there } \\
\text { was kinship between members after the } \\
\text { program. }\end{array}$ \\
\hline 9. & Soil fertility & $\begin{array}{l}\text { From the results of the questionnaire, } \\
98 \% \text { or } 24 \text { respondents stated that they } \\
\text { would use organic fertilizer to maintain } \\
\text { soil fertility. }\end{array}$ \\
\hline 10. & Water quality & $\begin{array}{l}\text { From the results of the questionnaire, } \\
98 \% \text { or } 24 \text { respondents stated that they } \\
\text { would use the right dosage of pesticides } \\
\text { to keep water pollution from happening. }\end{array}$ \\
\hline 11. & Air quality & $\begin{array}{l}\text { From the results of the questionnaire, } \\
98 \% \text { or } 24 \text { respondents stated that they } \\
\text { would process agricultural waste to } \\
\text { maintain no air pollution due to the odor } \\
\text { generated from agricultural waste. }\end{array}$ \\
\hline 12. & $\begin{array}{l}\text { Number of animal } \\
\text { preservation }\end{array}$ & $\begin{array}{l}\text { From the results of the questionnaire, } \\
92 \% \text { or } 23 \text { respondents stated that the } \\
\text { pesticides they used would not make the } \\
\text { insects die, so that they would preserve } \\
\text { animals. }\end{array}$ \\
\hline
\end{tabular}


90 | Shofia Hidayat, Hendro Wibowo, Muhammad Doddy: The Impact of Productive Zakat on The Economic Empowerment Program Based on Social Return on Investments (SR0I)

After determining the outcome to be analyzed and also the supporting indicators, SROI analysis must now determine the value of the outcome. Each outcome will have a financial proxy that will be used to calculate the total outcome (benefit) of a program / project.

Table 4: Impacts and Financial Proxy

\begin{tabular}{|c|c|c|c|}
\hline No. & Impacts & Financial Froxy & Amount \\
\hline 1. & Increased revenue & $\begin{array}{l}\text { Capital issued for } \\
\text { agriculture }\end{array}$ & Rp9.000.000,- \\
\hline 2. & Sales & Training costs. & Rp1.070.313, - \\
\hline 3. & Tax income & Cost of leasing land & Rp20.000.000,- \\
\hline 4. & Price Level Changes & Training costs. & Rp1.070.131,- \\
\hline 5. & Quality Change & Training costs. & Rp1.070.131,- \\
\hline 6. & $\begin{array}{l}\text { Increasing } \\
\text { Purchasing Power }\end{array}$ & $\begin{array}{l}\text { Cost of leasing land } \\
\text { and transportation. }\end{array}$ & Rp23.650.000,- \\
\hline 7. & Mutual cooperation & $\begin{array}{l}\text { Construction labor cost } \\
\text { for community } \\
\text { facilities building. }\end{array}$ & Rp980.000.000,- \\
\hline 8. & Kinship & Training costs. & Rp1.070.131,- \\
\hline 9. & Soil fertility & $\begin{array}{l}\text { Costs for purchasing } \\
\text { inorganic fertilizers. }\end{array}$ & Rp180.000,- \\
\hline 10. & Water quality & $\begin{array}{l}\text { Purchase costs for } \\
\text { appropriate pesticides. }\end{array}$ & Rp240.000,- \\
\hline 11. & Air quality & $\begin{array}{l}\text { Cost of purchasing } \\
\text { fertilizer. }\end{array}$ & Rp160.000,- \\
\hline 12. & $\begin{array}{l}\text { Number of animal } \\
\text { preservation }\end{array}$ & $\begin{array}{l}\text { Purchase costs for } \\
\text { appropriate pesticides. }\end{array}$ & Rp240.000,- \\
\hline
\end{tabular}

Source: Data processed

In the SROI handbook the maximum duration of time applied in the analysis is five years and a minimum of one year (Nicholls et al. 2009). The impact in this study lasted for five years and was calculated with a duration of five years. 
Jurnal Ekonomi dan Perbankan Syariah

Vol. 7. No.1, April 2019: 79-94 ISSN (cet): 2355-1755 | ISSN (online): 2579-

6437

| 91

Determining Impacts

Table 5: Determining Impacts

\section{Dampak Deadweight Displacement Atrribution Drop-off}

\begin{tabular}{|c|c|c|c|c|}
\hline $\begin{array}{l}\text { Increased } \\
\text { revenue }\end{array}$ & $4 \%$ & $0 \%$ & $20 \%$ & $10 \%$ \\
\hline Sales & $4 \%$ & $0 \%$ & $0 \%$ & $0 \%$ \\
\hline Tax income & $24 \%$ & $0 \%$ & $0 \%$ & $0 \%$ \\
\hline $\begin{array}{l}\text { Price Level } \\
\text { Changes }\end{array}$ & $0 \%$ & $0 \%$ & $0 \%$ & $0 \%$ \\
\hline $\begin{array}{l}\text { Quality } \\
\text { Change }\end{array}$ & $4 \%$ & $0 \%$ & $0 \%$ & $0 \%$ \\
\hline $\begin{array}{l}\text { Increasing } \\
\text { Purchasing } \\
\text { Power }\end{array}$ & $12 \%$ & $0 \%$ & $20 \%$ & $5 \%$ \\
\hline $\begin{array}{l}\text { Mutual } \\
\text { cooperation }\end{array}$ & $0 \%$ & $0 \%$ & $0 \%$ & $0 \%$ \\
\hline Kinship & $0 \%$ & $0 \%$ & $0 \%$ & $0 \%$ \\
\hline Soil fertility & $4 \%$ & $0 \%$ & $20 \%$ & $0 \%$ \\
\hline Water quality & $4 \%$ & $0 \%$ & $0 \%$ & $0 \%$ \\
\hline Air quality & $4 \%$ & $0 \%$ & $0 \%$ & $0 \%$ \\
\hline $\begin{array}{l}\text { Number of } \\
\text { animal } \\
\text { preservation }\end{array}$ & $8 \%$ & $0 \%$ & $0 \%$ & $0 \%$ \\
\hline
\end{tabular}

Source: Data processed

\section{SROI RESULTS}

SROI analysis is a means of informing funders about how much benefits the beneficiaries have felt, as optimal as what funds they have invested in this social program and as a means of evaluation for stakeholders for better empowerment programs. The SROI analysis conducted is one period, one year in 2018. 
92 | Shofia Hidayat, Hendro Wibowo, Muhammad Doddy: The Impact of Productive Zakat on The Economic Empowerment Program Based on Social Return on Investments (SR0I)

\begin{tabular}{rrr}
\hline \multicolumn{1}{c}{ Tahun } & Total Impact Value Per Year & NPV Per Year \\
\hline $\mathbf{1}$ & $959,303,504.00$ & $922,407,215.40$ \\
\hline $\mathbf{2}$ & $922,351,760.00$ & $854,029,407.40$ \\
\hline $\mathbf{3}$ & $869,722,006.00$ & $776,537,505.40$ \\
\hline $\mathbf{4}$ & $823,101,244.00$ & $703,505,336.80$ \\
\hline $\mathbf{5}$ & $780,789,182.00$ & $649,280,315.70$ \\
\hline Total & $4,355,267,696.00$ & $3,905,759,780.70$ \\
\hline
\end{tabular}

Based on the formula of SROI as follows, the result is:

SROI Ratio $=($ Net Present Value of Benefit $) /($ Value of Inputs $)$

$$
=3.905 .759 .780,70 / 798.882 .300=4,89
$$

The final result of SROI ratio was 4.89

\section{CONCLUSION}

The final result of this study found that the SROI ratio was 4.89: 1. Hence in other words, every Rp. 1 invested has generated Rp. 4.98 in economic, social and environmental benefits. This means that the empowerment program in the form of the Green Hortim M3 program which is based on the Sumber Jaya Tani Association has been able to provide benefits of 4.89 times greater than the value of the input invested.

From the programs held there have been twelve impacts which cover economic, social and environmental impacts, namely increasing income, increasing sales, tax revenues, changing price levels, changing quality, increasing purchasing power, family, mutual cooperation, maintaining soil quality, water, and air and animal preservation.

This shows that the Green Horti M3 empowerment program has been able to have an impact that brings benefits to the community, especially farmers who are members of the Sumber Jaya Tani Association so that farmers can improve their standard of living and knowledge in agricultural techniques so as to produce healthy agriculture and have maximum productivity. 
Jurnal Ekonomi dan Perbankan Syariah

Vol. 7. No.1, April 2019: 79-94 ISSN (cet): 2355-1755 | ISSN (online): 2579-

6437

193

\section{BIBLIOGRAPHY}

Agustina, Isna Fitria, and Ricka Oktaviani. 2016. "Analisis Dampak Sosial Dan Ekonomi Kebijakan Pengembangan Kawasan Mix Use Di Kecamatan Jabon." JKMP 4: 151-68.

Baznas. 2017. Statistik Zakat Nasional 2017. Jakarta: Baznas.

Baznas, Pusaka. 2018. Outlook Zakat Indonesia 2018. 1st ed. Jakarta pusat: pusat kajian

Darmawan, Deni. 2014. Metode Penelitian Kuantitatif. Bandung: PT.Remaja Rosdakarya.

Hasan, Ali.M. 2003. Masail Fiqhiyah. Jakarta: PT.Rajagrafindo persada.

https://www.kemsos.go.id/co. "Dampak Sosial." https://www.kemsos.go.id/content/dampak-sosial.

Kurniawati, Dwi Pratiwi, Bambang Supriyono, and Imam Hanafi. 2013. "Pemberdayaan Masyarakat Di Bidang Usaha Ekonomi (Studi Pada Badan Pemberdayaan Masyarakat Kota Mojokerto).” Jurnal Administrasi Publik I(4): 9-14.

Nicholls, Jeremy, Eilis Lawlor, Eva Neitzer, and Tim Goodspeed. 2009. "A Guide to Social Return on Investment." New economics foundation 3(January): 55.

P.H., Victor, and Nikijuluw. 2001. "Populasi Dan Sosial Ekonomi Masyarakat Pesisir Serta Stategi Pemberdayaan Mereka Dalam Konteks Pengelolaan Sumberdaya Pesisir Secara Terpadu." Makalah PElatihan Pengelolaan Pesisir Terpadu, Institut Pertanian Bogor 1: 160.

Purwohedi, Unggul. 2016. Social Return on Investment (SROI) : Sebuah Teknik Untuk Mengukur Manfaat/Dampak Dari Sebuah Program Atau Proyek. Yogyakarta: Leutikaprio.

Puskas, Baznas. 2017. Outlook Zakat 2017. Jakarta.

Qardawi, Yusuf.DR. 2011. Hukum Zakat. Bogor: Pustaka Litera AntarNusa.

Rabuhadi, Fani. 2006. "Sikap Dan Kesediaan Masyarakat Menerima Dampak 
94 | Shofia Hidayat, Hendro Wibowo, Muhammad Doddy: The Impact of Productive Zakat on The Economic Empowerment Program Rased on Social Return on Investments (SR0I) Lingkungan Usaha Peternakan Sapi Perah.” Institut Pertanian Bogor.

Rusli, Abubakar Hamzah, Sofyan Syahnur. 2013. “Analisis Dampak Pemberian Modal Zakat Produktif Terhadap Pengentasan Kemiskinan Di Kabupaten Aceh Utara." Jurnal Ilmu Ekonomi Pascasarjana Universitas Syiah Kuala 1(1): 56-63.

Sayyid, Sabiq. 2006. Fiqh Sunnah 1. Jakarta Selatan: Pena Pundi Aksara. 